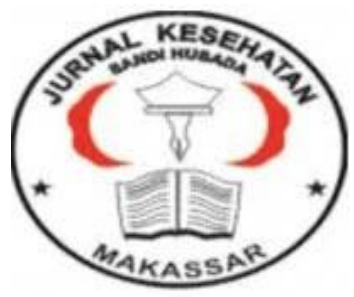

\author{
Jurnal Ilmiah Kesehatan Sandi Husada \\ hhttps://akper-sandikarsa.e-journal.id/JIKSH \\ Vol 9, No, 1, Juni 2020, pp;1-7 \\ p-ISSN: 2354-6093 dan e-ISSN: 2654-4563 \\ DOI: $10.35816 /$ jiskh.v10i2.193
}

\title{
Gambaran Nutrisi Lansia Di Desa Banua Baru
}

ARTIKEL PENELITIAN

Elderly Nutrition in Banua Baru Village

\author{
Fredy Akbar $\mathbf{K}^{\mathbf{1}}$, Idawati Ambo Hamsah ${ }^{2}$, Ayuni Muspiati $\mathbf{M}^{\mathbf{3}}$ \\ ${ }^{123}$ Keperawatan Institusi Akademi Keperawatan YPPP Wonomulyo
}

\section{Artikel info}

Artikel history:

Received; 17 Januari 2020

Revised; 18 Januari 2020

Accepted; 18 Januari 2020

\begin{abstract}
Elderly is the last phase in human life, where every aged person will definitely pass through this phase. As we age, all organ functions have reached their maximum peak so what is happening now is a decline in organ function. There are many elderly people in Indonesia who experience nutritional fulfillment disorders who experience malnutrition (BMI 16.5-18.49\%) as much as 31\% and more nutrition 1.8\%. Nutrition is less often caused by social and economic problems and also due to disease disorders, if the consumption of calories is too low than needed then the body weight is less than normal. The purpose of this study, to determine the amount of BMI and the type of nutritional intake in the elderly. The research design is quantitative descriptive. The study was conducted by measurements and observations made in one time with the inclusion criteria are the elderly who can be invited to communicate, using a design on the variable Screening Mini Nurtitional Assessment (MNA). The results of the study were obtained from 18 samples experiencing malnutrition and 20 samples of risk of experiencing malnutrition, while for the measurement of $B M I$ from the elderly obtained values of $0=B M I<19$; 19 people, value $1=$ BMI 19-21; 9 people, value 2 = BMI 21- 23; 6 people, value $3=$ BMI $>23 ; 4$ people.
\end{abstract}
Abstrak.
Lansia yaitu fase terakhir dalam kehidupan manusia, dimana setiap insan yang berumur pasti akan melewati fase ini. Semakin bertambahnya usia maka seluruh fungsi organ telah mencapai puncak maksimal sehingga yang terjadi sekarang adalah penurunan fungsi organ. lansia di Indonesia banyak yang mengalami gangguan pemenuhan gizi yang mengalami gizi kurang (IMT 16,5-18,49\%) sebanyak 31\% dan gizi lebih banyak 1,8\%. Gizi kurang sering di sebabkan oleh masalah social dan ekonomi dan juga karena gangguan penyakit, bila konsumsi kalori yang terlalu rendah dari yang dibutuhkan maka berat badan kurang dari normal. Tujuan dilakukannya penelitian ini, untuk mengetahui jumlah nilai IMT dan jenis asupan nutrisi pada lansia. Desain penelitian merupakan deskriptif kuantitatif. Penelitian dilakukan dengan pengukuran dan pengamatan yang dilakukan dalam satu waktu saja dengan kritetria inklusinya adalah lansia yang dapat diajak berkomunikasi, dengan menggunakan rancangan pada 
variable Skcreening Mini Nurtitional Asessment (MNA). Hasil penelitian didapat yaitu dari 18 sampel mengalami malnutrisi dan 20 sampel resiko mengalami malnutrisi, sedangkan untuk pengukuran IMT dari lansia didapatkan hasil nilai $0=I M T<19 ; 19$ orang, nilai 1=IMT 19-21;9orang, nilai 2=IMT 21-23;6 orang, nilai 3=IMT $>23 ; 4$ orang.

\author{
Keywords: \\ Lansia; \\ Malnutrisi; \\ Gizi lansia;
}

Coresponden author:

Email: fredykabira@gmail.com

artikel dengan akses terbuka dibawah lisensi CC BY -4.0

\section{Pendahuluan}

Menurut Kemenkes Indonesia, pertambahan presentase penduduk lanjut usia diseluruh dunia dibandingkan kelompok usia lainnya cukup pesat yaitu sejak tahun 2013 sebesar 13,4. Di Indonesia pada tahun 2013, jumlah lansia sudah mencapai 22,250 juta jiwa atau 8,9\%. (Nurfantri, 2016). Lansia yaitu fase terakhir dalam kehidupan manusia, dimana setiap insan yang berumur pasti akan melewati fase ini. Semakin bertambahnya usia maka seluruh fungsi organ telah mencapai puncak maksimal sehingga yang terjadi sekarang adalah penurunan fungsi organ. Menurut UU RI No. 13 Tahun 1998 tentang Kesejahteraan Lanjut Usia, yang dimaksud dengan Lanjut Usia (lansia) yaitu seseorang yang telah mencapai umur 60 tahun keatas, pada tahun 2013 jumlah penduduk lansia diseluruh dunia berjumlah 7,2 milyar. Jumlah penduduk lansia dengan jenis kelamin pria berjumlah 8.538.832 jiwa, sedangkan jumlah penduduk lansia dengan jenis kelamin perempuan 10.046.073 jiwa. (Boy, 2019). Dengan banyaknya usia yang telantar dan jumlah populasi usia yang naik dengan begitu cepatnya maka cepat atau lambat akan menjadi masalah apabila tidak dipersiapkan mulai dari sekarang, juga ada 2 penyebab langsung karena gizi kurang seperti penyakit infeksi dan tingkat asupan makanan.(Amran, Kusumawardani dan Supriyatiningsih, 2010).

Lansia di Indonesia banyak yang mengalami gangguan pemenuhan gizi yang mengalami gizi kurang (IMT 16,5-18,49\%) sebanyak 31\% dan gizi lebih banyak 1,8\%. Pengasuhan gizi mungkin memiliki efek positif pada asupan energy dan zat gizi yang lain serta kualitas hidup penduduk lansia dan lansia yang menderita malnutrisi. (Indraswari, Thaha dan Jafar, 2012). Adapun masalah gizi yang sering terjadi pada lansia adalah masalah gizi yang berlebih (obesitas) dan masalah gizi kurang (kurus) (Pesisir, 2009). Status gizi lansia yang abnormal dapat terjadi karena adanya perubahanperubahan yaitu dengan penurunan air liur, kultus dalam menelan, dan menunda pengosongan perut dan kerongkongan serta menurunkan gastroin yaitu gerakan testinal dimana masalah ini dapat mempengaruhi nutrisi dan sebagai salah satu yang paling penting didalam pemeliharaan kesehatan sehingga hasilnya yaitu lansia term aksud kelompok yang berpotensi rentang resiko kekurangan gizi. (Abolghasem Gorji et al., 2017). Status gizi ialah keadaan tubuh sebagai akibat konsumsi makanan dan penggunaan zat-zat. Satatus gizi seseorang dapat ditemukan oleh beberapa pemeriksaan gizi. Pemeriksaan actual gizi yang memberikan data paling meyakinkan tentang keadaaan actual gizi seseorang. Bagi lansia, pengukuran dan penentuan status gizi pada lansia ialah dengan menggunakan Indeks Massa Tubuh (IMT) dan Mini Nutritional Assesment (MNA). Indeks Massa Tubuh (IMT) atau biasa dikenal dengan Body Mass Index merupakan alat ukur yang sering digunakan untuk mengetahui kekurangan dan kelebihan berat badan seseorang, sehingga dapat mempertahankan berat badan normal yang memungkinkan seseorang dapat mencapai usia harapan hidup lebih panjang. Mini Nutiritonal Assesment (MNA) ialah salah satu alat ukur yang digunakan untuk screening status gizipada lansia.

Hal ini dilakukan untuk mengetahui apakah seorang lansia mempunyai resiko mengalami malnutrisi. Mini Nutritional Assesment (MNA) merupakan suatu alat skrining yang telah divalidasi secara khusus untuk lansia, memiliki sensifitas, dapat diandalkan, secara luas dapat digunakan sebagai metode skrining dan telah direkomendasikan oleh organisasi ilmiah dan klinis baik 
nasional maupun internasional. (V.A, 2014). Tujuan dari penelitian ini yaitu untuk mengetahui status gizi para lansia yang ada di desa Banua Baru dusun 1,2,3 dan 4 dengan ruang lingkup dalampenelitian ini hanya dibatasi pada pengkajian status giziterhadap lansia dengan usia diatas 60 tahun yang berada di desa Banua Baru, Kecamatan Wonomulyo. Berdasarkan uraian yang telah dijelaskan di atas, maka dalam hal ini peneliti tertarik untuk melihat bagaimana pola pengasuhan gizi lansia di desa Banua Baru dengan melakukan pemeriksaan IMT dan screening MNA.

\section{Metode}

Penelitian dilakukan pada tanggal 19 Desember 2019 di desa Banua Baru, Kecamatan Wonomulyo dengan desain penelitian ini menggunakan penilitian deskriptif kuantitatif. Penelitian dilakukan dengan pengukuran dan pengamatan status gizi pada lansia yang dilakukan dalam satu waktu saja. Populasi dalam penelitian ini ialah lanjut usia dengan kritetria inklusinya adalah lansia ( $>60$ tahun) yang dapat diajak berkomunikasi, dengan menggunakan rancangan pada variable Skcreening Mini Nurtitional Asessment (MNA) dan pengukuran IMT dengan alat ukur pengukuran Timbangan berat badan dan pita meteran. Pada tahap pertama diperlukan adanya pengumpulan data dengan tahap 1. Mempersiapkan alat maupun bahan yang akan digunakan dalam menunjang hasil observasi yang lengkap seperti Format Mini Nutritional Assesment (MNA). 2. Menetapkan jumlah sampel serta populasi (Usia 60tahun Keatas). 3. Dilanjutkan dengan melakukan pemeriksaan dan pengukuran IMT yaitu Tes Komposisi Tubuh (tes antopometri berupa tes berat badan, tes tinggi badan), 4 . Setelah itu menganalisis data yang telah didapat, 5. Setelah dianalisis simpulkan hasil yang telah didapatkan.

\section{Treatment}

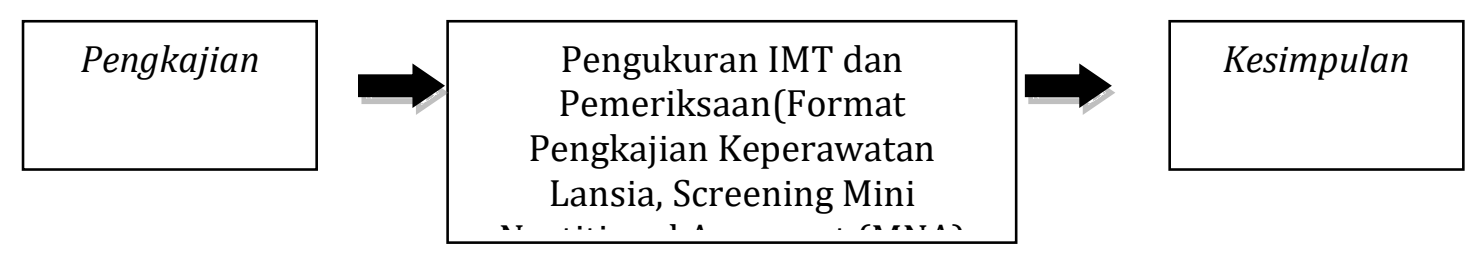

Gambar 2.1 Gambar Sistem Penelitian

Rancangan ini di ilustrasikan sebagai pola seperti berikut :

Keterangan :

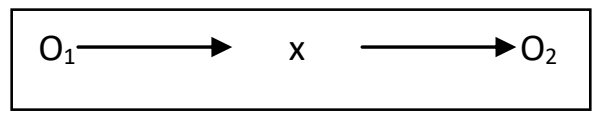

$\mathrm{O}_{1}$ : Pengkajian, sebelum dilakukan pengontrolan diet

$\mathrm{X}$ : Intervensi pengontrolan diet

$\mathrm{O}_{2}:$ Kesimpulan, hasil yang didapatkan

Populasi dalam penelitian ini adalah lansia yang berjumlah 38 sampel dengan menggunakan teknik Purposive Sampling dimana pengambilan sampel pada lansia dengan tujuan untuk mengetahui hasil IMT serta keadaan nutrisi pada lansia.

\section{Hasil Dan Pembahasan}

Dari hasil sampel yang didapatkan didesa Banua Baru dengan jumlah populasi yaitu 38 lansia dari berbagai dusun $(1,2,3,4)$ perempuan maupun laki-laki dengan krtiteria inklusinya usia diatas 60 tahun dengan melakukan pengukuran pengukuran IMT dari lansia didapatkan hasil seperti tabel berikut : 
Tabel 1 Analisisis Status Gizi Nilai IMT

\begin{tabular}{lcc}
\hline \multicolumn{1}{c}{ NILAI IMT } & $\mathbf{N}$ & $\mathbf{\%}$ \\
\hline Underweight & 19 & 50 \\
\hline Normal & 9 & 25 \\
\hline Over & 6 & 15 \\
\hline Obesitas & 4 & 10 \\
\hline Jumlah & 38 & 100
\end{tabular}

Sumber; Data Primer 2019

Menunjukkan tentang status gizi lansia di desa Banua baru berdasarkan pengukuran IMT menunjukan bahwa gizi tidak normal sebanyak 19 responden (50\%) dan gizi berlebih sebanyak 4 responden $(10 \%)$.

Tabel 2. Status Gizi Nilai MNA

\begin{tabular}{lcc}
\hline \multicolumn{1}{c}{ Status Gizi MNA } & N & \% \\
\hline Status Gizi Normal & 0 & 0 \\
\hline Resiko Mengalami Malnutrisi & 20 & 52,6 \\
\hline Mengalami Malnutrisi & 18 & 47,3 \\
\hline
\end{tabular}

Sumber; Data Primer 2019

Tabel di atas menunjukan hasil status gizi lanjut usia dengan melakukan pengukuran Mini Nutrition Assesment (MNA) bahwa terdapat lansia dengan resiko mengalami malnutrisi 20 responden $(52,6 \%)$ dan lansia yang mengalami malnutrisi 18 responden $(47,3 \%)$, sedangkan untuk status giz normal tidak ada responden.

\section{Indeks Massa Tubuh (IMT)}

Indeks Massa Tubuh (IMT) adalah salah satu alat untuk memantau status gizi orang dewasa, khusus yang berkaitan dengan kekurangan dan kelebihan berat badan. IMT dapat dilakukan dengan membagi berat badan individu ( $\mathrm{kg}$ ) dengan tinggi badan individu $\left(\mathrm{m}^{2}\right)$. Perhitungan IMT dapat diperoleh jika pengukuran berat badan dan tinggi lutut dilakukan terlebih dahulu sebelum dilakukan wawancara. Hal ini dilakukanuntuk mempermudah proses pengambilan data. Meningkatnya berat badan tubuh dapat menunjukan bertambhanya lemak tubuh atau adanya edema, dan penurunan berat badan dapat menunjukan adanya perkembangan penyakit asupan nutrisi yang kuran g pada lansia ataupun terjadinya kehilangan massa otot dan jaringan lemak. Pengukuran antropometri lain yang dapat dilakukan untuk menentukan status gizi lansia berdasarkan IMT yaitu pengukuran tinggi badan. Penentuan status gizi berdasarkan MNA mempunyai tujuan yaitu untuk mengetahui apakah seseorang berada pada kondisi risiko malnutrisi atau tidak sehingga dapat ditentukan intervensi gizi sejak dini tanpa membutuhkan penilaian oleh tim khusus gizi. Lansia dalam penelitian ini diwawancarai berdasar pada pertanyaan yanga da di dalam screening MNA untuk menetukan status gizi lansia berdasarkan MNA sehingga dalam pengambilan data yang bersifat subyektif karena jawaban didapat langsung dari lansia. (Wa Ode Sri Asmaniar, 2018).

Beberapa factor yang mempengaruhi seseorang mengalami kemungkinan malnutrisi terdapat didalam pertanyaan yang ada di screening MNA. Faktor tersebut diantaranya yaitu penurunan asupan makan selama 3 bulan terakhir, kehilangan berat badan, mobilisasi, strees psikologis atau penyakit akut, masallah neuropsikologis dan hasil perhitungan IMT. Berdasarkan hasil penelitian didapatkan lebih banyak lansia yang resiko mengalami malnutrisi dibandingkan dengan lansia yang malnutrisi dan nutrisi yang baik. 


\section{Pengetahuan Gizi}

Malnutrisi ialah keadaan patologis yang dihaislkan akibat defisiensi nutrisi. Cadangan gizi manusia yang habis sebagai akibat dari kecukupan asupan giziuntuk memenuhi kebutuhan nutrisi. Ketidakcukupan nutrisi diakibatkan dari gangguan dalam proses pencernaan makanan, pencernaan, atau penyerapan. Hal ini dapat terjadi akibat ketidakmampuan untuk mengkonsumsi nutrisi yang memadai, ketidakmampuan untuk mencerna nutrisi, ketidakmampuan untuk menyerap nutrisi atau peningkatan kebutuhan nutrisi oleh tubuh. Identifikasi awal dari kekurangan gizi atau resiko kekurangan gizi dapat menurunkan kejadian tersebut. Faktor yang mempengaruhi malnutrisi ialah penurunan nafsu makan, penurunan rasa dan bau, status kondisi kesehatan gigi dan mulut, disfagia, depresi, dan kondisi psikologis. Penurunan nafsu makan pada lanjut usia sangat berhubungan dengan jumlah intake makanan lanjut usia. Hal ini disebabkan oleh penurunan reseptor opioid dan opioid endogen pada otak, sehingga hal ini menurunkan kapasitas kerja dari sel tersebut dimana sel-sel itu berperan pada hasrat atau keinginan seseorang tersebut terhadap makanan. Hasil survey The Nutrition Diet And Nutrition Survey menunjukan bahwa akibat proses menua, lanjut usia yang berusia 65 tahu atau lebih mengalami penurunan jumlah gigi. Selain itu penurunan kemampuan mengunyah juga dijumpai pada populasi tersebut. Kedua hal tersebut berkontribusi pada intake nutrisi oral lanjut usia yang berdampak pada kondisi mikronutrien seperti kadar kalsium, zat besi, vit A,B,C,E. (Nurfantri, 2016)

Menurut salah satu peneliti bernama Koswara ditahun 2007 tentang masalah gizi yang dihadapi oleh lansia berkaitan erat dengan menurunnya aktifitas fisiologis tubuhnya. Konsumsi pangan yang kurang seimbang akan memperburuk kondisi lansia yang secara alami memang sudah menurun. Di bandingkan dengan usia dewasa, kebutuhan gizi lansia umunya lebih rendah karena adanya penurunan metabolisme basal dan kemunduran fungsi tubuh yang lain. Gizi kurang sering di sebabkan oleh masalah social dan ekonomi dan juga karena gangguan penyakit, bila konsumsi kalori yang terlalu rendah dari yang dubutuhkan maka berat badan kurang dari normal. Apabila hal ini disertai dengan kekurangan protein maka akan terjadi kerusakan-kerusakan sel yang tidak dapat diperbaiki sehingga menyebabkan rambut rontok, dan daya tahan menurun. Sedangkan gizi berlebih pada lanjut usia erat kaitannya dengan kebiasaan makan pada waktu muda. (Pesisir, 2009)

Penelitian yang dilakukan oleh salah satu peneliti bernama Muis mengatakan bahwa terjadinya kekurangan gizi pada lansia karena sebab-sebab yang bersifat primer maupun sekunder. Sebabsebab primer meliputi ketidaktahuan, isolasi social, hidup seorang diri, kehilangan pasangan hidup, gangguan fisik, gangguan indera, gangguan mental serta kemiskinan sehingga kurangnya asupan makanan. Sebab sebab sekunder meliputi malabsorbsi, penggunaan obat-obatan, peningkatan kebutuahn zat gizi serta alkoholisme sehingga faktor-faktor tersebut dapat menyebabkan malnutrisi pada lansia dan jika bergabung maka akan mengakibatkan keburukan nutrisi sehingga dapat membahayakan status kesehatan mereka. (Indraswari, Thaha dan Jafar, 2012). Asupan makanan merupakan faktor yang berpengaruh langsung secara linier dalam menentukan status gizi seseorang. Konsumsi makan berpengaruh terhadap status gizi seseorang. Jikia lansia mengkonsumsi lebih dari $3.500 \mathrm{kcal}$, maka kelebihan dari kebutuhan tersebut dapat memproduksi 0,45 kg lemak. Kelebihan $1000 \mathrm{kcal}$ per hari akan menambah $1 \mathrm{~kg}$ timbunan lemak per minggu. Dengan demikian, orang yang makan berlebih secaratetrus menerus akan mudah mengalami obesitas. Seseorang dengan asupan energy tidak cukup, beresio 3,2 kali lebih beesar untuk mengalami kekurangan gizi dibandingkan dengan subjek yang asupan energinya cukup.(Ninna Rohmawati \& Susetyowati, 2015)

\section{Lanjut Usia}

Lanjut usia (lansia) yaitu seseorang yang mencapai usia 60 tahun keatas. Menua bukanlah suatu penyakit, tetapi merupakan proses menurunnya daya tahan tubuh didalam menhadapi ransangan dari dalam dan diluar tubuh dan berakhir dengan kematian. (Putri, Rosyid dan Muhlisin, 2014). Kualitas hidup ialah kondisi fungsional lansia yang meliputi kesehatan fisik, kesehatan psikologis, dukungan social, dan kondisi lingkungan. Kualitas hidup merupakan konsep dari beberapa dimensi yang mencakup kesehatan fisik, mental, psikologis, dan kesejahteraan, terkadang juga dapat 
dikatakan sebagai kepuasan hidup. Kualitas hidup yang baik dimiliki oleh seseorang dengankebiasaan mengatur pola makan, gaya hidup yang baik, rutin memeriksakan kesehatan dan rajin mengikuti programpenyuluhan, sedangkan kualitas hidup kurang dimiliki seseorang dengan kebiasaan meningkatkan risiko paparan penyakit. Dalam segi kesehatan, kualitas hidup dapat disamakan dengan keadaan kesehatan, fungsi fisik tubuh, perceived health status, kesehatan subyektif, persepsi mengenai kesehatan, kognisi individu, ketidakmampuan fungsional, gangguan psikatri dan kesejahteraan. Kualitas hidup yang baik dapat dilihat dari status gizi yang baik. Pemenuhan kebutuhan gizi yang baik dapat membantu proses adaptasi dengan perubahan yang dialami dan dapat menjaga kelangsungan pergantian sel-sel tubuh sehingga dapat memperpanjang usia. (Nursilmi, 2017).

Seperti yang telah dijelaskan oleh peneliti Oktariyani pada tahun 2016 bahwa banyakanya lanjut usia yang berada dalam resiko malnutrisi disebabkan karena faktor usia yang dapat menyebabkan perubahanpada system pencernaan lanjut usia dan adanya faktor resiko yang mempengaruhi status gizi lanjut usia seperti faktor psikologi, adanya riwayat penyakit serta jumlah dan jenis asupan makanan. Berdasarkan hasil dari penelitian ini didapatkan tentang gambaran asupan makanan lanjut usia dalam 3 bulan terakhir dimana terdapat lanjut usia yang kehilangan penurunan asupan makanan yang besar sebanyak 1 orang, kehilangan penurunan asupan makanan yang sedang sebanyak 2 orang, dan yang tidak ada penurunan asupan makanan sebanyak 35 orang. Dengan bertambahnya usia maka kemampuan dalam mengecap, mencerna dan menyerap makanan akan berkurang, sehingga lanjut usia kurang menikmati makanan dan kurang asupan makanan yang bias mengakibatkan penurunan nafsu makan (Wa Ode Sri Asmaniar, 2018). Dalam penelitian ini didapatkan bahwa pada lanjut usia yang mengalami penurunan berat badan $>3 \mathrm{~kg}$ selama 3 bulan terakhir sebanyak 2 orang, lanjut usia yang tidak mengetahui penurunan berat badan sebanyak 6 orang, lanjut usia yang mengalami penurunan berat badan 1-3kg sangat banyak yaitu sebanyak 22 orang, sedangkan lanjut usia yang tidak mengalami penurunan berat badan yaitu 8 orang. Pengukuran berat bad an sangat menentukan dalam penilaian status gizi dari seseorang dalam memiliki gizi berlebih ataupun gizi yang kurang. (Wa Ode Sri Asmaniar, 2018). Mobilitas menunjukan bahwa lebih dari setengah lansia yang dapat turun dari tempat tidur/kursi roda namun tidak dapat berjalan jauh sebanyak 31 orang, lanjut usia yang dapat berjalan jauh hanya 7 orang, sedangkan 0 orang yang tidak dapat turun dari tempat tidur/kursi roda. Pada penelitian ini lanjut usia tidak dapat melakukanaktifitas yang berlebih namun dapat melakukan kemampuan dalam pergerakan fisik secara mandiri .

Dari hasil penelitian yang didapat setengah dari lanjut usia tidak mengalami stress psikologis sebanyak 25 orang, sedangkan lanjut usia yang mengalami stress psikologis sebanyak 13 orang. Pemikiran yang positif dari lanjut usia tentang kondisi kesehatannya dapat meningkatkan status kesehatan lanjut usia. Hal ini dikarenakan jika lanjut usia berpikiran negatif tentang kondisi kesehatannya menyebabkan lanjut usia cenderung untuk stress dan dapat mempengaruhi kondisi psikologis lanjut usia dan pada akhirnya berpengaruh terhadap status gizi lanjut usia itu sendiri. Dari hasil penelitian ini juga dapat dilihat sebanyak 2 orang yang mengalami masalah neuropsikologis demensia berat, 30 orang yang mengalami tingkat sedang dan 6 orang yang tidak mengalami neuropsikologis atau demensia. Hal ini terjadi secara perlahan seiring bertambahnya usia, terjadinya penurunan dalam ingatan atau dalam melakukan aktifitasnya misalkan makan. Gejala demensia yang terjadi pada lanjut usia biasanya diawali dengan kemunduran memori atau daya ingat sehingga beberapa aktifitas sering dilupakan (Wa Ode Sri Asmaniar, 2018).Penentuan status gizi menggunakan IMT dan dan MNA dapat digunakan secara bersama-sama meskipun hasil menunjukan bahwa jumlah lanjut usia yang memiliki status gizi normal berdasarkan IMT hamper sama dengan jumlah lanjut usia yang memiliki status gizi normal berdasarkan MNA, namun pengaktegorian kedua jenis penentuan status gizi ini berbeda, sehingga jika digunakan bersama dapat melengkapi dan mendapatkan informasi yang lebih akurat terkait status gizi lansia. (Wa Ode Sri Asmaniar, 2018). 


\section{Simpulan Dan Saran}

Status gizi berdasarkan Indeks Massa Tubuh (IMT) didapatkan data bahwa lansia dengan IMT < 19; 19 Orang, IMT 19-21; 9 orang, IMT 21-23; 6 orang, IMT $>23 ; 4$ orang. Sedangkan untuk status gizi menggunakan Mini Nutritional Asesssment (MNA) didapatkan data bahwa 18 sampel mengalami malnutrisi, 20 sampel resiko mengalami malnutrisi dan 0 sampel yang mengalami nutrisi baik. Dalam penilian MNA dan Pengukuran IMT lebih mudah dan praktis untuk digunakan dalam menilai status gizi yang bernilai objektif. Adapun saran yang dapat diberikan yaitu :

1. Diharapkan pada desa setempat untuk melakukan pemeriksaan status gizi pada lansia secara rutin dan berkala baik menggunakan IMT maupun MNA.

2. Sebaiknya keluarga melakukan pengawasan makanan pada lansia.

\section{Daftar Rujukan}

Abolghasem Gorji, H. et al. (2017) "The prevalence of malnutrition in iranian elderly: A review article," Iranian Journal of Public Health, 46(12), hal. 1603-1610.

Amran, Y., Kusumawardani, R. dan Supriyatiningsih, N. (2010) "Food Intake Determinant Factor Among Elderly," Kesehatan Masyarakat Nasional, 6(6), hal. 255-260.

Boy, E. (2019) "Prevalensi Malnutrisi Pada Lansia Dengan Pengukuran Mini Nutritional Asessment (Mna) Di Puskesmas," Herb-Medicine Journal, 2(1), hal. 5-9. doi: 10.30595/hmj.v2i1.3583.

Indraswari, W., Thaha, A. R. dan Jafar, N. (2012) "Pola Pengasuhan Gizi Dan Status Gizi Lanjut Usia Di Puskesmas Lau Kabupaten Maros Tahun 2012 Nursing Of Nutrition Aspects And Nutritional Status Among Elderly In Lau Health Center Maros Regency 2012 Program Studi Ilmu Gizi , Fakultas Kesehatan Masyarakat,"

Http://Pasca.Unhas.Ac.Id/Jurnal/Files/58C4192Eb29F12D853198579Fb322C33.Pdf, hal. 115.

Ninna Rohmawati, A. H., \& Susetyowati, N. R. (2015). Tingkat kecemasan, asupan makan, dan status gizi pada lansia di Kota Yogyakarta , 69-71.

Nurfantri, D. Y. (2016). Identifikasi Status Nutrisi Dan Resiko Malnutrisi Pada Lanjut Usia Di Panti Sosial Tresna Werdha Minaula Kota Kendari , 5-7.

Nursilmi, C. M. (2017). Hubungan Status Gizi Dan Kesehatan Dengan Kualitas Hidup Lansia Di Dua Lokasi Berbeda , 376-379.

Pesisir, K. R. (2009) “Faktor - Faktor Yang Mempengaruhi Status Gizi Lansia Novia Sartika 1 , Reni Zulfitri 2 , Riri Novayelinda 3," hal. 39-49.

Putri, R. A., Rosyid, F. N. dan Muhlisin, A. (2014) "Hubungan Antara Tingkat Pengetahuan Tentang Diet Hipertensi Dengan Kejadian Kekambuhan Hipertensi Lansia Di Desa Mancasan Wilayah Kerja Puskesmas I Baki Sukoharjo," Journal of UMS, hal. 1-12.

V.A, P. Z. (2014). Hubungan Status Gizi Terhadap Kebugaran Lansia Di Paguyuban Senamkarang Weda Jambangan Surabaya , 2-8.

Wa Ode Sri Asmaniar, A. A. (2018). Analisis Status Gizi Lansia Berdasarkan Indeks Massa Tubuh (Imt) Dan Mini Nutritional Assesment (MNA). 3-6. 